Proc. Estonian Acad. Sci. Biol. Ecol., 2002, 51, 3, 173-183

\title{
History of ice research in the Baltic Sea along the Estonian coast
}

\author{
Svetlana Jevrejeva \\ Tallinn Pedagogical University, Narva mnt. 25, 10120 Tallinn, Estonia; sveta.jevrejeva@ neti.ee \\ Received 28 March 2001, in revised form 1 October 2001

\begin{abstract}
The oldest records about ice along the Estonian coast, found in the Tallinn Town Archives, date from the 14th century. Regular observations were organized since the 1860 s with a network of observation stations established at coastal lighthouses. Information about ice conditions was recorded in journals, preserved to the present day in the archive of the Estonian Meteorological and Hydrological Institute. These data have been used in many studies and scientific publications.
\end{abstract}

Key words: Baltic Sea, ice conditions, historical information, regular ice observations.

\section{INTRODUCTION}

Ice observations in the Baltic Sea have long traditions. The oldest records about ice along the Estonian coast, found in the Tallinn Town Archives, date from the 14th century (Tarand, 1993). The safety and efficiency of sea transportation, offshore operations, and fisheries encouraged the development of sea ice observations.

Two major periods can be identified in the Baltic Sea ice research: (1) up to the mid-19th century, for which information is mostly obtained from records in chronicles and other sources, and (2) from the 1860s onward - the period of regular observations when data have been collected from a network of observation stations.

The history of ice observations in Estonia prior to 1940 was shortly described by Mardiste as part of his two articles on the history of hydrological investigations of the Estonian coastal sea up to 1917 (Mardiste, 1995) and in 1918-40 (Mardiste, 1999a), both in the Estonian language.

Data from more than 40 stations situated along the Estonian coast covering about 120 years of observations have been used in many scientific projects and researches. However, the number of publications during the last 60 years was not 
large. The aim of the present paper is to give a survey of the history of ice observations in the Baltic Sea along the Estonian coast and of the use of observation data in research work.

Writing this paper helped me understand that the present-day climate might be seen just as a fleeting picture in a long chain of changes and that we cannot yet ordinarily define the fundamental variability of the climate. If we wish to get our own climate and our ideas about ongoing changes in the climate into perspective, it is useful to look back in time.

\section{REGULAR ICE OBSERVATIONS ALONG THE ESTONIAN COAST}

The first ice observations in the eastern part of the Gulf of Finland were made at the lighthouse of Kronstadt in 1814. Since 1860 a network of observation stations (Vyborg in 1861 and on the island of Hogland in 1873) was established at coastal lighthouses (Rykachev, 1886). Observation results were recorded in journals. The Main Hydrographic Office of Russia issued special instructions and observation forms in 1886. The programme of observations included the date of first freezing, date of ice break-up, thickness of ice, and the possibility of using the ice cover for transportation and communication, especially between islands and the mainland. The first observations along the Finnish coast (Helsinki) were made in 1829; however, regular observations started at the Hanko lighthouse only in 1893 (Grönvall, 1988).

Sporadic and unsystematic ice observations along the Estonian coast were carried out in Paldiski in 1859-79, in Pärnu in 1860-79, in Kuressaare in 1860 78, and at Sõrve in 1866-79 (Rykachev, 1886). Later the first regular ice observations were arranged by the Main Hydrographic Office at the lighthouses of Vaindloo in 1888, Tallinn, Vilsandi, Narva-Jõesuu, and Naissaar in 1889, Vormsi in 1893, Osmussaar in 1894, and Kihnu in 1895. The observation programme included information on the date of the first freezing and the formation of the permanent ice cover, date of the break-up of the permanent ice cover, the final disappearance of the ice, and the thickness of the ice. During the ice period air temperature measurements were made. The observations were recorded in journals and preserved to the present day (Table 1) in the archive of the Estonian Meteorological and Hydrological Institute (EMHI). An example of observation journals from Vormsi Island (1895 and 1923) is shown in Fig. 1.

An observation network (19 stations), based on lighthouses, was established at the beginning of the 20th century. The first ice reports were published by Shpindler (1888, 1893a, 1893b). In 1908 a more detailed programme of sea ice observations, including ice drift, its velocity and direction, and ice development, was applied. A new classification of ice quantity of 10-point scale was used. New observation stations were established along the coast. By special agreement the icebreakers and other vessels were obliged to supply the Main Hydrographic Office of Russia information about ice, including observations at the ice margins. 
Table 1. Estonian observation network with periods for which data on ice conditions are available. Currently operating stations are shown in boldface

\begin{tabular}{|c|c|}
\hline Station & Periods of observations \\
\hline Abruka & $1910 / 11-1962 / 63$ \\
\hline Aegna & $1930 / 31-1939 / 40$ \\
\hline Haapsalu & $1922 / 23-1939 / 40,1947 / 48-1956 / 57$ \\
\hline Heltermaa & $1947 / 48-1999 / 2000$ \\
\hline Häädemeeste & $1930 / 31-1939 / 40$ \\
\hline Keemu & $1926 / 27-1941 / 42$ \\
\hline Keri & $1906 / 07-1913 / 14,1922 / 23-1939 / 40$ \\
\hline Kihnu & 1894/1895-1916/17, 1921/22-1939/40, 1949/50-1999/2000 \\
\hline Kingissepa & $1949 / 50-1957 / 58$ \\
\hline Kunda & $1948 / 49-1999 / 2000$ \\
\hline Kõpu & $1903 / 04-1913 / 14,1922 / 23-1939 / 40$ \\
\hline Kübassaare & $1923 / 24-1939 / 40$ \\
\hline Loksa & 1923/24-1929/30, 1950/51-1957/58, 1995/96-1999/2000 \\
\hline Merise & $1949 / 50-1962 / 63$ \\
\hline Mohni & $1903 / 04-1913 / 14,1922 / 23-1939 / 40$ \\
\hline Muuga & $1984 / 85-1999 / 2000$ \\
\hline Naissaar & 1888/89-1916/17, 1922/23-1939/40, 1949/50-1992/93 \\
\hline Narva-Jõesuu & 1903/04-1913/14, 1922/23-1939/40, 1948/49-1999/2000 \\
\hline Osmussaar & 1903/04-1916/17, 1922/23-1939/40, 1952/53-1971/72 \\
\hline Pakri & 1903/04-1913/14, 1922/23-1939/40, 1950/51-1998/99 \\
\hline Paldiski & $1923 / 24-1925 / 26,1954 / 55-1999 / 2000$ \\
\hline Prangli & 1949/50-1955/56, 1966/67-1998/99 \\
\hline Puise & $1932 / 33-1939 / 40$ \\
\hline Purtse & $1930 / 31-1939 / 40,1946 / 47-1963 / 64$ \\
\hline Põõsaspea & 1929/30-1934/35, 1939/40, 1949/50-1999/2000 \\
\hline Pärnu & 1893/94-1910/11, 1920/21-1939/40, 1944/45-1999/2000 \\
\hline Raugi & $1923 / 24-1939 / 40,1947 / 48-1963 / 64$ \\
\hline Ristna & $1922 / 23-1939 / 40,1948 / 49-1999 / 2000$ \\
\hline Rohuküla & $1949 / 50-1999 / 2000$ \\
\hline Rohuneeme & $1949 / 50,1955 / 56-1998 / 99$ \\
\hline Roomassaare & $1922 / 23-1923 / 24,1925 / 26-1939 / 40$ \\
\hline Ruhnu & 1903/04-1913/14, 1922/23-1939/40, 1947/48-1999/2000 \\
\hline Suurpea & $1960 / 61-1994 / 95$ \\
\hline Suurupi & $1916 / 17,1922 / 23-1939 / 40,1947 / 48-1954 / 55$ \\
\hline Sõru & $1923 / 24-1934 / 35,1947 / 48-1989 / 90$ \\
\hline Sõrve & 1903/04-1913/14, 1922/23-1939/40, 1951/52-1999/2000 \\
\hline Tahkuna & 1903/04-1913/14, 1922/23-1939/40, 1950/51-1966/67 \\
\hline Tallinn & 1903/04-1906/07, 1908/09-1916/17, 1923/24-1939/40, 1948/49-1995/96 \\
\hline Toila & $1989 / 90-1999 / 2000$ \\
\hline Toolse & $1929 / 30-1939 / 40$ \\
\hline Tsitre & $1949 / 50-1955 / 56$ \\
\hline Vaindloo & 1888/89-1994/95, 1903/04, 1906/07-1916/17, 1923/24-1939/40 \\
\hline Viinistu & $1949 / 50-1962 / 63$ \\
\hline Viirelaid & $1888 / 89-1916 / 17,1922 / 23-1939 / 40$ \\
\hline Vilsandi & 1908/09-1913/14, 1922/23-1939/40, 1949/50-1999/2000 \\
\hline Virtsu & $1904 / 05-1916 / 17,1922 / 23-1923 / 24,1929 / 30-1939 / 40,1947 / 48-1999 / 2000$ \\
\hline Vormsi & $1892 / 93-1916 / 17,1922 / 23-1939 / 40,1947 / 48-1963 / 64$ \\
\hline
\end{tabular}




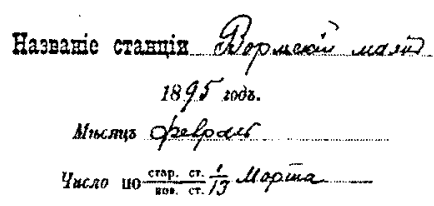

\section{СВБДБНІЯ О СОСТОЯНІИ ЛЬДА.}

1. Ітогда показазея дедт?

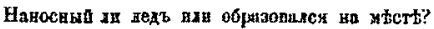

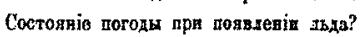

2. Эахерзsо an sope y zorдa?

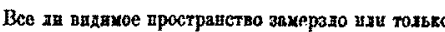

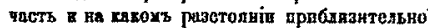

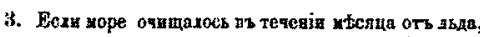

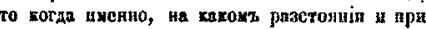

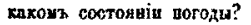

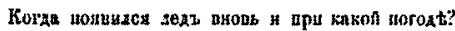

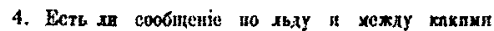
IT

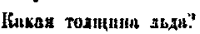

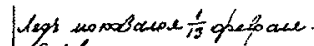

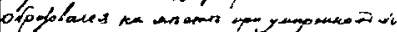

mesmpanpa - $11 X$.

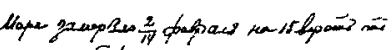

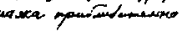

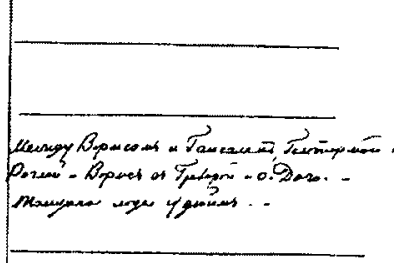

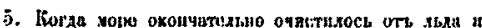
дри какой nosort?

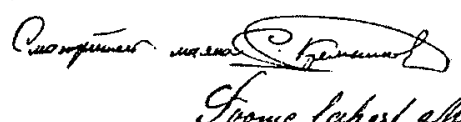

Jää vaatlused.

Kont: YOrmsi tulaters

кии Xesficen 1923

\begin{tabular}{|c|c|c|c|c|c|c|c|}
\hline so & $i$ & L I l k y y Ja: ; & & s & e $15=v 13$ & Oreat & \\
\hline$\underline{\underline{B}}$ & Palli & 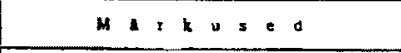 & Pastit & $\begin{array}{l}\text { Pak- } \\
\text { sus }\end{array}$ & $M \geq r k 4 \leq E d$ & plie- & Lecres: \\
\hline $\bar{v} 1$ & 6 & 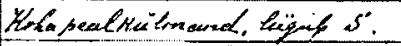 & 11 & & Ramace zearalex. & 3 & \\
\hline$\sqrt{2}$ & 6 & Qyisicies menested & $\angle$ & & & 5 & 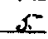 \\
\hline$\sqrt{3}$ & 5 & $\therefore \varkappa$ & 1 & & & 7 & 6 \\
\hline 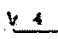 & 6 & Eaciall Eaktione & 1 & & & $s$ & 6 \\
\hline 55 & 6 & Hohn peal resitom midel. & 1 & & & 3 & 5 \\
\hline 46 & 3 & Oyinjein & 6 & & & $z$ & 4 \\
\hline$\sqrt{7}$ & 5 & $\because \quad S^{\prime}$ & 1 & & & 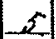 & 4 \\
\hline 68 & 4 & $\therefore s^{\prime}$ & 1 & & & 2 & 4 \\
\hline Y & $Z$ & Laktine ming expon $"-E$ & $\angle$ & & & 3 & 4 \\
\hline 610 & 8 & 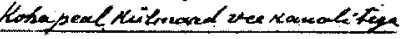 & 1 & & & 3 & $s$ \\
\hline w11. & $=$ & & 12 & & 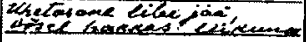 & 3 & 6 \\
\hline 12 & 9 & 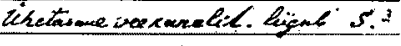 & - & & & 24 & \\
\hline $\mathrm{V} 13$ & 9 & 1 - necinakm Zivenege & - & & & 6 & $\gamma$ \\
\hline v14 & $=$ & & 10 & & 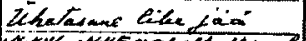 & 6 & $z$ \\
\hline$\sqrt{15}$ & $\angle$ & 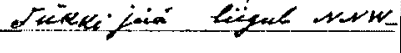 & 8 & & $\pi$ & & \\
\hline
\end{tabular}

Fig. 1. Records of ice observation data in journals (1895 in Russian and 1923 in Estonian) from the Vormsi station. 
During World War I most of the observation stations stopped working. The Estonian national observation network gradually grew up after 1919. Numerous new observation stations were established (Haapsalu, Loksa, Paldiski, Põõsaspea, Ristna, Sõru). The network was so comprehensive that it was possible to describe the ice conditions and restrictions to navigation for all Estonian ports. The ice reports were also given by number codes by radio. Estonia, Finland, and Sweden made an agreement to use a common ice code in 1925 (Lisitzin, 1979). The observation programme was detailed and information about various types of drift ice, ice concentration, thickness of ice and snow cover, and possibilities of navigation for sailing ships and for steamers was available.

During World War II the observations were cancelled. After the war the whole observation network was reorganized. Ice observations from aircraft were started. These observations covered the Gulf of Finland, Gulf of Riga, and the Väinameri (Moonsund). The sea ice data were usually summarized in yearbooks every year. Since 1959 the observation programme has changed notably. Detailed measurements of ice drift, ice thickness, and observations of the development of ice have been included in the programme.

At present the EMHI is responsible for the sea ice observations and sea ice information service in Estonia. Daily ice information is reported from 16 coastal stations, situated along the Estonian coast. In addition to the daily information, each of the stations makes weekly ice charts and some short description of the thickness of fast ice with the depth and density of snow cover on it. Most observations are visual. Automatization has not yet reached the coastal stations. Ice information collected from the observation stations is analysed and distributed in the form of ice reports, ice charts, and forecasts of ice conditions to the customers. The service is in particular intended to meet the needs of Estonian and international shipping companies. It also gives the required information to fisheries, coastal and harbour activities, weather forecasting, and climatology.

\section{PUBLICATIONS BASED ON REGULAR OBSERVATIONS}

On the basis of data collected on the ice conditions papers discussing the properties of ice as well as the variations in the ice conditions began to appear in the scientific literature already at the end of the 19th century. Some descriptions of ice conditions along the Estonian coast can be found in a book on freezing and ice break-up in the Russian Empire by Rykachev (1886). Shpindler (1988, 1893a) studied ice conditions on the Baltic Sea and published several articles. The ice cover in the Gulf of Riga was treated by Rudovic (1918). A number of reports have been published in Finland on the statistical properties of ice conditions in the Gulf of Finland containing time series, tables, and ice atlases. An atlas of ice conditions of the Baltic Sea along Finland was published by Jurva (1937). The Baltic ice extent and ice conditions along the coast of Finland have been examined by Jurva (1944), Palosuo (1953), Makkonen et al. (1984), Leppäranta \& Seinä (1985), Seinä (1993), and Haapala \& Leppäranta (1997). A climatological 
ice atlas for the Baltic Sea, Kattegat, Skagerrak, and Lake Vänern for 1963-79 was published by the Swedish Meteorological and Hydrological Institute and the Institute of Marine Research in Finland (SMHI \& FIMR, 1982). There are also some publications in Russia that describe the general features of the ice regime in the Baltic Sea with some detailed analysis of ice conditions in the Gulf of Finland (Arnold-Alyabev, 1924, 1938; Betin, 1957; Betin \& Preobrazhenskij, 1962). Such publications are largely lacking for the Estonian waters. The first description of ice conditions in the Väinameri was published by Sass (1866) for the period 1851-62.

From the winter of 1923/24 onward the University of Tartu published every year data on sea ice with a short summary (Beobachtungen des Meereises im Winter, 1923/24-1937/38). For the winter of 1938/39 the data and a description of ice conditions (Anon., 1940) were published by the Natural Resources Research Institute, founded in 1937.

Among scientists studying sea ice in the first half of the 20th century K. Frisch deserves special mentioning. He published descriptions of ice conditions in Tallinn Bay from 1895/96 to 1913/14 (Frisch, 1924) and presented new results concerning ice conditions along the Estonian coast on the 4th Hydrological Conference of the Baltic States in Leningrad in 1933 (Frisch, 1933). Later a few internal reports were produced in the EMHI.

From 1951 to 1991 short descriptions of ice conditions were presented in marine hydrometeorological yearbooks and marine hydrometeorological monthly reports. However, those issues were not available for public. Alekseeva (1967) described ice conditions and traffic on ice during the winter seasons in the Straits of Muhu. Mardiste (1971a, 1971b, 1999a) published results of detailed analysis of the ice conditions and their influence on the traffic between West Estonian islands and the mainland. He also presented a short description of ice observations and ice research within the history of hydrological investigations along the Estonian coast up to 1940 (Mardiste, 1995, 1999b). Vahter (1994) treated the ice regime in Tallinn and Muuga bays. More recently, results from analysis of longterm series of ice conditions in the Baltic Sea along the Estonian coast were published by Jevrejeva $(1999,2000,2001)$ and Jevrejeva \& Leppäranta (2001).

Data collected from the observation network along the Estonian coast of the Gulf of Riga have been published mostly by scientists from Latvia: Pastors (1965), Kostyukov (1979), Kostyukov \& Zakharchenko (1988). These data have also been used in many publications by the State Oceanographic Institute (Anon., 1992).

On the basis of the collected datasets several atlases and a reference book (all in Russian) were published: an atlas of ice in the Baltic Sea (Gulf of Riga, Danish Straits, and the surrounding part of the North Sea) and the surrounding areas (in 1960); an atlas of ice in the Baltic Sea (the Gulf of Finland and the Gulf of Bothnia) and the surrounding areas (in 1961); an atlas of maximum ice extent in the Gulf of Riga (in 1965); and a reference book on the hydrological regime of the seas and river estuaries of the USSR (in 1971). 


\section{RESEARCH BASED ON HISTORICAL INFORMATION ON ICE CONDITIONS}

The Baltic is the only sea in Europe covered by ice every winter. Descriptions of ice conditions are documented in many historical records. Brief descriptions of sea ice occasionally appeared as fragments in the travel literature. For instance, according to historical records the Baltic Sea was covered by fast ice between Sweden and Estonia in 1269 (Jurva, 1937); a road was established between Revel (Tallinn) and Denmark in 1459; the Russian army crossed the Gulf of Bothnia from Finland to Sweden in 1809. Detailed depiction of a variety of activities can be found on the chart "Carta Marina" produced by Olaus Magnus in 1539. It shows crossings made by horse-drawn sledges between Finland and Sweden near the central part of the Gulf of Bothnia. In the eastern part of the Gulf of Finland a battle is sketched.

These early observations have contributed greatly also to our knowledge of climate variations on the Baltic Sea. Historical information has been used in several studies.

Ice conditions along Saaremaa Island (1843/44-1861/62) were reconstructed by A. F. Sass using the data collected at Kuivastu and Orissaare post offices and Kuressaare port. On the basis of those data Sass (1886) obtained the number of days with ice and dates of the freezing of water and ice break-up.

Jurva (1944) constructed a time series of maximum annual ice extent for a period of 122 years. This work was continued by Palosuo (1953) and Seinä \& Palosuo (1996). It was done on the basis of information from lighthouse diaries, which normally contained ice descriptions. Information from newspapers since 1771 was also analysed. The end and the beginning of navigation were regulated considering ice conditions, which had a significant influence on every-day life. Additionally air temperature measurements started in Stockholm since 1750 and in Helsinki since 1820 were used.

Tarand (1993) constructed a time series of ice break-up in the port of Tallinn since 1501. Tarand \& Toompuu (1998) published an article where they reconstructed and analysed an air temperature time series dating back for five centuries.

For the Western Baltic Sea analysis of ice conditions was carried out in terms of a mass-related severity index by Koslowski \& Loewe (1994) and Koslowski \& Glaser (1995). Reconstruction of seven types of winter severity was based on the accumulated areal ice volume along the German coast of the Baltic during 15011995. Variations in winter ice severity in the Western Baltic were investigated and periods with increased and reduced severity were defined. Relationships between different types of ice winter severity in the Western Baltic and the North Atlantic oscillation were examined.

Jevrejeva (2001) reconstructed ice conditions in the Baltic Sea during the winter seasons since 1529. She defined three types of winter seasons (mild, average, and severe), using historical records of ice break-up dates at the port of Riga and other historical information. Riga is one of the Hanseatic cities with a 
long history of trade. Numerous historical chronicles include descriptions of ice conditions as an important factor in the regulation of navigation. Stakle (1936) published the first time series of ice break-up at the port of Riga, which were then extended by Betin (1957) and Betin \& Preobrazhenskij (1962). The data for the period 1957-90 were obtained from yearbooks at the library of the EMHI. Reconstruction results were compared with available long-term time series of winter temperature from Uppsala (1720-1990), Stockholm (1756-1990), and St. Petersburg (1751-1979). Time series of the dates of ice break-up since 1529, arranged according to the severity of winter seasons, were examined. A decreasing linear trend of about 2 days per century, indicating an earlier break-up during spring, statistically significant at $99.9 \%$ level, was detected only for severe winter seasons, for the mild and average winters the trends were statistically insignificant; however, periods with a tendency to early and late break-up were defined. There were no fixed cycles in the time series, which indicates that ice break-up is more like a quasi-periodical process.

\section{ACKNOWLEDGEMENTS}

This work was supported by the Estonian Ministry of Education. I am grateful to anonymous reviewers for constructive criticism. I express my deep respect and acknowledgement to all the observers who have performed the invaluable fieldwork at the stations during centuries.

\section{REFERENCES}

Alekseeva, L. V. 1967. Ice conditions of the Straits of Muhu. Publ. Hydrometeorol. Observ. Tallinn, 5, 30-54 (in Russian).

Anon. 1940. Merejää vaatlused Eestis 1938./1939. aasta talvel. Loodusvarade Instituudi Avaldised (Tallinn).

Anon. 1992. Baltic Sea. In Project "Seas of the USSR", pp. 320-329. Gidrometeoizdat, St. Petersburg.

Arnold-Alyabev, V. I. 1924. Navigation in the Gulf of Finland and the Baltic Sea with the assistance of icebreakers, recent experience. Marine Coll. Publ., 10, 1924 (in Russian).

Arnold-Alyabev, V. I. 1938. Ice conditions in the Baltic Sea and their investigation. Publ. U.S.S.R. Sci. Eng.-Techn. Soc., Leningrad Branch. 2-3, 85-116 (in Russian).

Beobachtungen des Meereises im Winter. 1923/24-1937/38. Tartu Ülikooli Eesti Veekogude Uurimise Komisjoni Väljaanne, Nos. 1-31.

Betin, V. V. 1957. Ice conditions in the Baltic Sea region and their interannual variations. Publ. State Oceanogr. Inst., 41, 54-125 (in Russian).

Betin, V. V. \& Preobrazhenskij, J. V. 1962. Severity of the Winters in Europe and Ice on the Baltic Sea. Gidrometeoizdat, Leningrad (in Russian).

Frisch, K. 1924. Die Eisverhältnisse der Revaler Reede und ihre Beziehungen zur Lufttemperatur und Wassertemperatur der Ostsee. Loodusuurijate Seltsi aruanded, 31, 1-16.

Frisch, K. 1933. Average distribution of ice along the coast of Estonia. In 4th Hydrological Conference of the Baltic States. Leningrad.

Grönvall, H. 1988. Finnish ice service. Finn. Mar. Res., 256, 95-110. 
Haapala, J. \& Leppäranta. M. 1997. The Baltic Sea ice season in changing climate. Boreal Environ. Res., 2, 93-108.

Jevrejeva, S. 1999. Some results from the analysis of long-term time series regarding ice conditions along the Estonian coast. In Proceedings of Conference POAC'99, Vol. 1, pp. 354-363. Espoo, Finland.

Jevrejeva, S. 2000. Long-term variability of sea ice and air temperature conditions along the Estonian coast. Geophysica, 36, 17-30.

Jevrejeva, S. 2001. Severity of winter seasons in the northern Baltic Sea during 1529-1990: reconstruction and analysis. Clim. Res., 17, 55-62.

Jevrejeva, S. \& Leppäranta, M. 2001. Ice conditions along the Estonian coast in a statistical view. Nordic Hydrol., 33 (in press).

Jurva, R. 1937. Atlas der Eisverhältnisse der Baltischen Meeres an den Küsten Finnlands. Helsinki.

Jurva, R. 1944. Über die Eisverhältnisse des Baltischen Meeres an den Küsten Finnlands. Merentutkimuslaitoksen Julk., 114, 67-112.

Koslowski, G. \& Glaser, R. 1995. Reconstruction of the ice winter severity index since 1701 in the Western Baltic. Clim. Change, 31, 79-98.

Koslowski, G. \& Loewe, P. 1994. The Western Baltic Sea ice seasons in terms of a mass-related severity index 1879-1992. Part I. Temporal variability and association with the North Atlantic oscillation. Tellus, 46A, 66-74.

Kostyukov, J. L. 1979. Ice conditions of the Gulf of Riga. In Ice Condition Assessments in Hydrometeorological Services to Winter Navigation in the Baltic Sea. Gidrometeoizdat, Leningrad (in Russian).

Kostyukov, J. L. \& Zakharchenko, E. N. 1988. Regime-forming factors of the Gulf of Riga. In Regime-Forming Factors, Hydrometeorological and Hydrochemical Processes in the Seas of the USSR, pp. 50-61. Gidrometeoizdat, Leningrad (in Russian).

Leppäranta, M. \& Seinä, A. 1985. Freezing, maximum annual ice thickness and breakup of ice on the Finnish coast during 1830-1984. Geophysica, 21, 87-104.

Lisitzin, E. 1979. The Institute of Marine Research in Finland 1919-1968. Finn. Mar. Res., 246, $161-172$.

Makkonen, L., Launiainen, J., Kahma, K. \& Alenius, P. 1984. Long-term variations in some physical parameters of the Baltic Sea. In Climatic Changes on a Yearly to Millennial Basis (Mörner, N.-A. \& Karlen, W., eds.), pp. 391-399. Reidel.

Mardiste, H. 1971a. Väinamere jääteed. Eesti Loodus, 2, 87-91.

Mardiste, H. 1971b. On ice conditions in the Straits of Muhu (the Väinameri) and the use of iceroads. Acta Comm. Univ. Tartuensis. Publ. Geogr., 288, 44-54 (in Russian).

Mardiste, H. 1995. Eestit piirava mere hüdroloogilise uurimise ajalugu kuni 1917. aastani. In Teaduse ajaloo lehekülgi Eestist, Vol. 11, pp. 58-78. Estonian Academy Publishers, Tallinn.

Mardiste, H. 1999a. Eesti rannikumere hüdroloogiline uurimine aastail 1918-1940. In Yearbook of the Estonian Geographical Society, Vol. 32, pp. 81-90. Estonian Academy Publishers, Tallinn.

Mardiste, H. 1999b. Ice conditions in the Väinameri and their influence on the traffic between West-Estonian islands and the mainland. In Proceedings of Second Workshop on the Baltic Sea Ice Climate. Publ. Inst. Geogr. Univ. Tartuensis, 84, 37-43.

Palosuo, E. 1953. A treatise on severe ice conditions in the Baltic Sea. Merentutkimuslaitoksen Julk./Havsforskningsinst., 156, 130-131.

Pastors, A. A. 1965. Ice Extent in the Gulf of Riga, with Appended Atlas of Extent in the Gulf of Riga. Hydrometeorological Service of the State Committee for Hydrometeorology of the Latvian SSR, Riga (in Russian).

Rudovic, L. F. 1918. Ice Cover of the Gulf of Riga. Petrograd (in Russian).

Rykachev, M. A. 1886. The Break-up and Freezing on the Russian Empire. St. Petersburg (in Russian). 
Sass, A. F. 1866. Beobachtungen über das Treibeis in der Ostsee. Mittheilungen aus Justus Perthes' Geographischer Anstalt über Wichtige Neue Erforschungen auf dem Gesammtgebiete der Geographie von Dr. A. Petermann. Gotha, 426-427.

Sass, A. F. 1886. Untersuchungen über die Eisbedeckung des Meeres an den Küsten der Inseln Ösel und Moon. Bull. Acad. Imp. Sci. St. Pétersbourg, 9, 145-188.

Seinä, A. 1993. Ice time series of the Baltic Sea Ice Climate. Rep. Ser. Geophys. (Department of Geophysics, University of Helsinki), 27, 87-90.

Seinä, A. \& Palosuo, E. 1996. The classification of the maximum annual extent of ice cover in the Baltic Sea 1720-1995. Meri, 27, 79-91.

Shpindler, I. B. 1888. Freezing and break-up in the Baltic Sea along the Finnish coast. Zap. gidr., 2, 1-24 (in Russian).

Shpindler, I. B. 1893a. Freezing and break-up along the Russian coast. Zap. gidr., 14, 1-44 (in Russian).

Shpindler, I. B. 1893b. Ice cover of the Baltic Sea in 1892/93. Zap. gidr., 14, 44-58 (in Russian).

SMHI \& FIMR. 1982. Climatological ice atlas for the Baltic Sea, Kattegat, Skagerrak and Lake Vänern 1963-1979. Norrköping and Helsinki.

Stakle, P. 1936. Die Eisverhältnisse der Ostsee und ihre Erforschung. In 5. Hydrologische Konferenz der Baltischen Staaten. Bericht 13a. Helsinki.

Tarand, A. 1993. The Tallinn time series of break-up as climate indicator. Rep. Ser. Geophys. (Department of Geophysics, University of Helsinki), 27, 91-93.

Tarand, A. \& Toompuu, A. 1998. Estonian climate: reconstructions based on historical and modern data. In Proceedings of the Second International Conference on Climate and Water, Espoo, 17-20 August, 1998, Vol. 2, pp. 849-862.

Vahter, R. 1994. Tallinna ja Muuga lahe jääolud. In Year-book of the Estonian Geographical Society, Vol. 26, pp. 19-31, Estonian Academy Publishers, Tallinn.

\section{Eesti rannikumere jäävaatluste ja jääuuringute ajaloost}

\section{Svetlana Jevrejeva}

Peaaegu igal talvel kattub Eesti rannikumeri jääga, välja arvatud soojadel talvedel, kui jää esineb ainult ranna ääres. Paks jääkate raskendab oluliselt laevasõitu Läänemerel ning seda peab arvestama hüdrotehniliste ehitiste projekteerimisel ja rajamisel. Seettõttu on vajalikud jäärežiimi uuringud, mis ühtlasi annavad ülevaate kliima muutumisest ja aitavad hinnata veekogu ökoloogilist seisundit. Lühikokkuvõtte jääolude uurimisest on avaldanud H. Mardiste (1995, 1999a) kahes artiklis. Tema kirjutised haaravad perioodi vaatluste algusest kuni 1940. aastani. Siinne artikkel kirjeldab Eesti rannikumere vaatlusvõrgust kogutud jääandmete alusel tehtud uurimistöid tänapäevani.

Vanimad jäävaatlusandmed pärinevad 14. sajandist ja need asuvad Tallinna Linnaarhiivis (Tarand, 1993). Jäänähteid registreeriti ja pandi episoodiliselt kirja Paldiskis aastail 1859-1879, Pärnus 1860-1879, Kuressaares 1860-1878 ja Sõrves 1866-1879. Regulaarseid jäävaatlusi hakati organiseerima tuletornides: Vaindloo - 1888, Tallinn, Vilsandi, Narva-Jõesuu ja Naissaar - 1889, Vormsi - 1893, Osmussaar - 1894, Kihnu - 1895. 1886 valmistas Venemaa Hüdrograafia Peavalitsus ette spetsiaalsed küsimustikud jäänähete registreerimiseks ja kohustas tuletornivahte ettenähtud vormi kohaselt saatma teateid jääst. Nõuti infot jää 
tekkimise, mere kinnikülmumise, jää paksuse, jää faaside arenemise ja jää kadumise kohta. Jäävaatluste vihikuid säilitatakse Eesti Meteoroloogia ja Hüdroloogia Instituudi fondis. Talletatud on ka rohkem kui 40 ranniku ja saarte vaatluspunkti andmed jäärežiimi kohta aastatel 1890-2000. Need sisaldavad teateid jäätekke, jää lagunemise, jääkatte ja muu osas.

Aastatel 1866-1918 ilmus palju Läänemere talviseid jääolusid puudutavaid artikleid, mille aluseks olevad andmed on saadud kõikidest Eesti rannikul paiknevatest vaatluspostidest (Špindler, 1888, 1893a, 1893b; Sass, 1866, 1886; Rõkatšov, 1886; Rudovic, 1918 ja teised).

1920/21. aasta talvest vaatluspunktide arv suurenes (lisandusid Haapsalu, Loksa, Põõsaspea, Sõru, Paldiski, Keemu ja Raugi) ning mõnevõrra täienes ka vaatluste programm. Alates 1923/24. aastast avaldati vaatlusandmed trükis Tartu Ülikooli Eesti Veekogude Uurimise Komisjoni väljaannetena. 1938/39. aasta talve vaatlusandmed publitseeris Loodusvarade Instituut. 1933. aastal tutvustas K. Frisch jäärežiimi uurimise tulemusi Läänemere maade hüdroloogia konverentsil Leningradis.

Pärast Teist maailmasõda on Eesti rannikumere vaatlusvõrgust kogutud ulatuslik materjal. Jäävaatluste kokkuvõtteid on kasutatud mereaastaraamatute ja mereatlaste koostamisel. Need aga olid salastatud väljaanded ja nende kasutamine oli piiratud.

Praegusel ajal teeb Eesti Meteoroloogia ja Hüdroloogia Instituudi vaatlusvõrk jäävaatlusi rannikumerel. Koostatakse igapäevaseid jääkaarte, mis võeti aluseks üldistatud jääkaartide tegemisel. Lähteandmetena kasutati lisaks standardsetele jäävaatlustele rannikujaamades jäälennuluure kaarte ja jääteateid laevadelt. 